\title{
PERBANDINGAN DAYA HAMBAT AIR BELERANG DARI SUMBER AIR PANAS NATAR DENGAN SUMBER AIR PANAS WAY BELERANG KALIANDA TERHADAP PERTUMBUHAN JAMUR Trichophyton mentagrophytes
}

\author{
Ayu Trimutia' ${ }^{1}, M_{a r h a m a h}{ }^{1}$, Eka Sulistianingsih ${ }^{1}$ \\ ${ }^{1}$ Program Studi Teknologi Laboratorium Medis Program Sarjana Terapan Jurusan Analis \\ Kesehatan Politeknik Kesehatan Tanjungkarang
}

[email korespondensi: ayuutrimutiaa@gmail.com]

\begin{abstract}
Comparison of The Responsibility of Slumpur Water from Natar Hot Water Sources with Kalianda Way Substances Hot Water on The Growth of The Mushrooms Trichophyton mentagrophytes. Trichophyton mentagrophytes fungal infection can be found almost in Indonesia, because it is a good area for fungal growth. The incidence of diseases caused by fungi in 2009-2011 ranged from 2,93 to $27,6 \%$ in Indonesia. One of them is Trichophyton mentagrophytes. Treatment of skin fungus there are 2 ways using chemical drugs and water containing sulfur. The purpose of this study was to determine the sulfur content of the Natar hot springs and the Way Sulfur Kalianda hot springs, and to compare the inhibitory power of the Natar hot springs with the Kalianda hot springs on the growth of the fungus Trichophyton mentagrophytes. This type of research is descriptive laboratory analysis. Independent $T$ test data analysis. The results showed that the sulfur content of the Natar hot springs was $0,001 \mathrm{mg} / \mathrm{L}$ and the Way Sulfur Kalianda was $1,736 \mathrm{mg} / \mathrm{L}$ in the inhibition zone for the growth of Trichophyton mentagrophytes, the Natar hot springs averaged $16.8 \mathrm{~mm}$ in the strong category, while the water of Way Sulfur Kalianda was 22,24 $\mathrm{mm}$ very strong category.
\end{abstract}

Keywords: Sulfur water, Trichophyton mentagrophytes

\begin{abstract}
Abstrak: Perbandingan Daya Hambat Air Belerang dari Sumber Air Panas Natar dengan Sumber Air Panas Way Belerang Kalianda Terhadap Pertumbuhan Jamur Trichophyton mentagrophytes. Infeksi jamur Trichophyton mentagrophytes dapat ditemukan hampir di wilayah Indonesia, karena merupakan wilayah yang baik untuk pertumbuhan jamur. Insidensi penyakit yang disebabkan oleh jamur pada tahun 2009-2011 berkisar 2,93-27,6\% Indonesia. Salah satunya jamur Trichophyton mentagrophytes. pengobatan jamur kulit ada 2 cara menggunakan obat kimia dan air yang mengandung belerang. Tujuan penelitian ini mengetahui kadar air belerang dari sumber air panas Natar dengan sumber air panas Way Belerang Kalianda, dan mengetahui perbandingan daya hambat air belerang air panas Natar dengan air panas Way Belerang Kalianda terhadap pertumbuhan jamur Trichophyton mentagrophytes. Jenis penelitian ini adalah deskriptif analisis laboratorium. Analisis data uji T Independent. Hasil penelitian menunjukkan kadar air belerang pemandian air panas Natar $0,001 \mathrm{mg} / \mathrm{L}$ dan kadar Way Belerang Kalianda 1,736 mg/L zona hambat terhadap pertumbuhan jamur Trichophyton mentagrophytes, pemandian air panas Natar rata-rata $16,8 \mathrm{~mm}$ katagori kuat sedangkan air Way Belerang Kalianda $22,24 \mathrm{~mm}$ kategori sangat kuat.
\end{abstract}

Kata Kunci: Air belerang, Trichophyton mentagrophytes 


\section{PENDAHULUAN}

Infeksi oleh jamur dapat ditemukan hampir di wilayah Indonesia karena merupakan wilayah yang baik untuk pertumbuhan jamur. Tingginya angka prevalensi ini dipengaruhi oleh letak geografis dan iklim negara Indonesia, selain itu perilaku masyarakat seperti mata pencarian dan tempat tinggal juga dapat menyebabkan interaksi dengan jamur. Jamur pada umumnya dapat cepat berkembang di tempat yang lembab, juga dapat berpindah melalui media air (Siregar, 2004).

Dermatofitosis merupakan salah satu penyakit yang disebabkan oleh jamur golongan dermatofita.Dermatofita merupakan golongan jamur yang mampu mencerna keratin dan epidermis.Trichophyton mentagrophytes merupakan salah satu jenis jamur yang menyebabkan dermatofitosis (Khusnul dkk, 2017).

Bahaya infeksi jamur tidak sekadar menyebabkan panu atau kurap saja, tapi juga bisa menyebabkan kematian bila infeksinya meluas dan bahkan masuk ke organ dalam tubuh (Bramono, 2004). Belerang memiliki khasiat bakterisid dan fungisid berdasarkan dioksidasinya menjadi asam peptathionat (H2S5O6) oleh kuman dikulit, ketika air belerang diterapkan pada kulit, air belerang mampu berinteraksi dengan sistein, hadir dalam stratum corneum, untuk membentuk hydrogen sulfide yang dapat memecah keratin, sehingga menunjukkan aktivitas keratolitik belerang (Sweetman didalam Rindu, 2019).

Belerang banyak digunakan pada terapi penyakit kulit yang disebabkan oleh penyakit jamur, Ketika diaplikasikan di kulit, belerang akan dikonversikan menjadi asam pentathionat oleh bakteri yang ada di kulit dan keratinosit. Selain itu, aktivitas keratolitik dari belerang juga dapat membantu menghilangkan jamur dari stratum korneum (Adlia dkk, 2019).

Hasil observasi yang telah dilakukan penulis pada bulan Agustus di pemandian air panas di Natar dan Way Belerang Kalianda. Pemandian air panas tersebut merupakan salah satu wisata alam yang terletak di Natar dan Kalianda yang ramai pengunjung, tidak jarang pengunjung yang memiliki keluhan penyakit kulit datang untuk berendam di kolam air panas yang diketahui baik untuk kesehatan dan kesembuhan kulit. Berdasarkan hasil wawancara dengan salah satu petugas dipemandian air panas bahwa jumlah pengunjung setiap harinya dipemandian air panas Natar berjumlah 60 orang sedangkan dipemandian air panas Way belerang Kalianda berjumlah 87 orang.

\section{METODE}

Jenis penelitian bersifat deskriptif analisis laboratorium. Terdapat dua variabel yang digunakan yaitu variabel independen/bebas yang merupakan air belerang Natar Merak Batin Kabupaten Lampung Selatan dan air Way belerang Kalianda Kabupaten Lampung Selatan serta variabel dependen/terikat adalah Pertumbuhan jamur Trichophyton mentagrophytes. Pemeriksaan ini menggunakan metode difusi Kirby Bauer dengan melihat zona hambat yang terbentuk.Kontrol positif yang digunakan dalam pengujian yaitu ketokonazol dan kontrol negatif yang digunakan yaitu aquadest steril.Pengulangan dilakukan sebanyak 6 kali yang dapat dihitung dengan menggunakan rumus Frederer yaitu $(\mathrm{t}-1)(\mathrm{n}-1) \geq 15$. 
HASIL

Tabel 1. Kadar Air Belerang Dari Sumber Air Panas Natar dengan Way Belerang Kalianda di Kabupaten Lampung Selatan

\begin{tabular}{|c|c|c|c|c|c|c|c|c|c|}
\hline \multicolumn{10}{|c|}{ Kadar $\mathrm{H}_{2} \mathrm{~S}$ Di } \\
\hline \multicolumn{4}{|c|}{ Air Panas NatarWay } & \multicolumn{6}{|c|}{ Belerang Kalianda } \\
\hline \multicolumn{4}{|l|}{$0,001 \mathrm{mg} / \mathrm{L}$} & \multicolumn{6}{|c|}{$1,736 \mathrm{mg} / \mathrm{L}$} \\
\hline \multicolumn{10}{|c|}{$\begin{array}{l}\text { Tabel 2. Diameter Zona Hambat Air Panas Natar Dengan Way Belerang } \\
\text { Kalianda Terhadap Pertumbuhan Jamur Trichophyton mentagrophytes }\end{array}$} \\
\hline \multirow[t]{2}{*}{ Sampel } & \multicolumn{6}{|c|}{$\begin{array}{c}\text { Diameter Zona Hambat pada } \\
\text { masing-masing pengulangan }(\mathrm{mm})\end{array}$} & \multirow[t]{2}{*}{$\begin{array}{l}\text { Jumlah } \\
(\mathrm{mm})\end{array}$} & \multirow[t]{2}{*}{$\begin{array}{l}\text { Rerata } \\
(\mathrm{mm})\end{array}$} & \multirow[t]{2}{*}{$\begin{array}{l}\text { Kategori } \\
\text { Zona } \\
\text { Hambat }\end{array}$} \\
\hline & I & II & III & IV & $\mathrm{V}$ & VI & & & \\
\hline $\begin{array}{l}\text { Air Panas } \\
\text { Natar }\end{array}$ & 14,3 & 20,8 & 20,6 & 14,3 & 17,8 & 13,0 & 100,8 & 16,8 & Kuat \\
\hline $\begin{array}{l}\text { Way Belerang } \\
\text { kalianda }\end{array}$ & 21,0 & 24,6 & 25,6 & 20,06 & 20,2 & 22,0 & 133,46 & 22,24 & $\begin{array}{l}\text { Sangat } \\
\text { Kuat }\end{array}$ \\
\hline Kontrol $(+)$ & 40,4 & & & & & & 40,4 & 40,4 & $\begin{array}{l}\text { Sangat } \\
\text { Kuat }\end{array}$ \\
\hline Kontrol (-) & 0,00 & & & & & & 0,00 & 0,00 & Lemah \\
\hline
\end{tabular}

Keterangan:

Kontrol (-): Aquades

Kontrol $(+)$ : Ketokonazol

\section{PEMBAHASAN}

Berdasarkan tabel 1, kadar belerang $\left(\mathrm{H}_{2} \mathrm{~S}\right)$ yang terdapat pada pemandian air panas Way Belerang Kalianda 1,736 mg/L dan pemandian air panas Natar 0,001 mg/L. Menurut Sylvi (2008), bahaya paparan senyawa belerang bagi tubuh ditentukan oleh dosis (jumlah senyawa yang masuk), durasi (lama paparan) dan cara kontak (cara masuk senyawa). Menurut SNI 19-0232-2005 belerang yang diizinkan adalah 5,2 mg/m3 (1,98 ppm). Menurut Permenaker No. 5 dari Nilai Batas Ambang Batas (TLV) 2018 untuk belerang adalah $0,25 \mathrm{mg} / \mathrm{m} 3 \quad(0,09542$ ppm). Menurut Sudarsono di dalam Ma'or dkk (2006), asam pentathionat $\left(\mathrm{H}_{2} \mathrm{~S}_{5} \mathrm{O}_{6}\right)$ pada belerang memiliki repon terhadap jamur Trichophyton mentagrophytes dengan mekanisme kerja menghancurkan protein dinding sel jamur Trichophyton mentagrophytes dan meyebabkan lisis pada membran sel. Menurut Alsuhendra \& Ridawati (2008), mekanisme antifungi lisisnya membran sel meyebabkan perubahan permaebelitas membran dan kerusakan membran yang akhirnya molekul dalam sitoplasma jamur Trichophyton mentagrophytes akan keluar sehingga menyebabkan kematian sel.

Berdasarkan hasil observasi yang telah dilakukan di pemandian air panas natar, rendahnya kadar $\mathrm{H}_{2} \mathrm{~S}$ pada air panas Natar dikarnakan dilokasi ini tidak terdapat gunung berapi, sedangkan di pemandian Way Belerang Kalianda yang terletak di lereng gunung Rajabasa. Menurut Bronto di dalam Darmawan (2013), kerucut vulkanik gunung Rajabasa memiliki ketinggian $\pm 1281 \mathrm{mdpl}$ dan merupakan gunung api aktif tipe B, Manifestasi panas bumi seperti mata air hangat, air belerang ditemukan di kaki Gunung Rajabasa. Air belerang di pemandian ini ada yang muncul dari bawah kolam, dan ada juga yang mengalir langsung dari gunung Rajabasa Kalianda Lampung Selatan. Menurut Wuisan didalam Rozki (2011), belerang terbentuk dari aktivitas vulkanis gunung 
berapi, dimana di Indonesia masih banyak gunung berapi yang masih aktif,Belerang secara visual berwarna kuning pucat, dan memiliki wujud padat pada suhu ruangan dan bisa berwujud cair maupun gas pada suhu tertentu. Menurut Febryani (2017), pengunjung yang datang untuk berendam durasi mandipun beragaman tetapi ratarata pengunjung berendam selama 15-20 menit dan memiliki kondisi yang cukup baik.

Setelah dilakukan analisa uji $\mathrm{T}$ didapatkan hasil rata-rata zona hambat air panas Natar 16,8 mm dengan katagori kuat terhadap pertumbuhan jamur Trichophyton mentagrophytes, sedangkan Way Belerang Kalianda sebesar 22,24 mm katagori sangat kuat terhadap pertumbuhan jamur Trichophyton dan diameter zona hambat pada ketokonazol sebesar 40,4 mm. Air belerang jika dibandingkan dengan ketokonazol berbeda, karena ketokonazol mengandung senyawa antifungi yang murni dan lebih efektif terhadap jamur Trichophyton mentagrophytes. Mekanisme kerja ketokonazol menghambat enzim sitokrom Porphyrin 450 (P-450), C-14alfa-demethylase yang bertanggung jawab mengubah lanosterol menjadi ergosterol, Hal ini mengakibatkan dinding sel jamur menjadi bocor dan jamur mengalami penghancuran (Lubis, 2008).

Faktor lain yang mempengaruhi perbedaan zona hambat yaitu temperatur inkubasi, waktu pemasangan cakram, perendaman cakram dengan air belerang , jarak cakram saat ditempelkan pada media agar dan ketebalan media agar pada cawan petri (Presscott, 2005).

Pemandian air panas Way Belerang Kalianda kemampuanya lebih tinggi menghambat pertumbuhan jamur Trichophyton mentagrophytes dibandingkan pemandian air panas Natar.

\section{DAFTAR PUSTAKA}

Adlia, A., Sakinah, A., Annis, C.A., Deandra, A.G., Vidy, A.R., Heni, R. (2019). Pemberdayaan Masyarakat Melalui Pelatihan Pembuatan Sabun
Sulfur Untuk Pencegahan Dermatitis. Darmabakti Cendekia: Journal of Community Service and Engagements 1(2): 45-49.

Alsuhendra \& Ridawati. (2008). Prinsip Analisis Zat Gizi dan Penilaian Organoleptik Bahan Makanan. Jakarta: UNJ Press.

Bramono, K. (2004). Pemaparan Tentang Jamur. Jakarta: FKUI.

Darmawan, I Gede Boy, Lucas Donny Setijadji, Djoko Wintolo. (2013). Interprestasi Geologi Gunung Rajabasa Berdasarkan Integrasi Citra Aster, Dem Dan Geologi Permukaan. Jurnal, Fakultas Teknik Geologi, Universitas Gadjah Mada.

Khusnul., Hindana, R., Kusmariani., W. (2017). Uji Efektivitas Ekstrak Etanol Rimpang Lengkuas (Alpinia galangal L) Terhadap Pertumbuhan Trichophyton rubrum Secara In Vivo. Jurnal Kesehatan Bakti Tunas Husada 17(1).

Kurniati,Rosita,C. (2008). Etiopatogenesis Dermatofitosis,Jurnal FK Unair,Surabaya.

Lubis DR. (2008). Pengobatan Dermatomikosis, Fakultas

Kedokteran, Universitas Sumatera Utara.

Permenaker No 5. (2018). Keselamatan Dan Kesehatan Kerja Lingkungan Kerja, Kementrian Ketenagakerjaan RI. Jakarta

Prescott, L.M, Harley, J.P dan Klein, D.A. (2005). Microbiology, Ed Ke-6. New York: Mc- Graw-Hill.

Rozki R.I. (2011). Nalisa Turap Kantilever Pada Tanah Pasir Mengandung Belerang, Fakultas Teknik Sipil, Universitas Sam Ratulangi.

Siregar, R. S. (2004). Penyakit Jamur Kulit Edisi Kedua. Jakarta: EGC.

SNI. (2005). Nilai Ambang Batas (NAB) Zat Kimia Di Udara Tempat Kerja, SNI 19-0232-2005, Jakarta.

Sudarsono, Nelva Karmila Jusuf. (2012). SPA Ditinjau Dari Segi Dermatologi Kosmetik. Fakultas Kedokteran. Sumatera Utara. 
Sweetman, Sean C. (2002). Martindale The Complete Drug Reference Thirty-Third Edition. London: Pharmaceutical Press.

Sylvi Anitasari, Gunawan Wibisono. (2008). Hubungan Antara Lama Paparan Uap Belerang Dengan Derajat Keparan Gingivitis. [Artikel Karya Ilmiah]. Semarang: Fakultas Kedokteran, Universitas Diponegoro. 